\title{
Kinetic considerations on thermophilic digestion of maize silage at different operating modes
}

Katarzyna Golkowska, Nomathamsanqa Nonjabulo Beierlein, Manfred Greger

\section{Introduction}

Unlike aerobic digestion the anaerobic fermentation can be characterised by a lower microbial energy consumption and biomass growth. The energy produced during substrate conversion is saved in form of methane, which can be further utilized as an energy source. The anaerobic systems tend to instabilities caused mainly by overloading or inappropriate operating conditions. Models help to describe and understand the degradation steps within a fermenter. Therefore they may be used to improve the design and operation of the biogas reactors. Models of lab scale tests allow a better data interpretation as well as deliver helpful information for the scale-up. The complexity of a model is always defined by how accurate the different processes of the system should be described and what the model destination is. For simulation of anaerobic processes models describing aerobic systems were adapted.

The simplest model to describe the biomass degradation by microbial culture is the first order model. In its equation it defines the substrate utilisation rate as function of substrate concentration only (s. Eq. 2, Chapter 3.2). Many aspects such as heterogeneity of the substrate, microbial growth and decay, as well as any sort of inhibition are not included in the equation. The $1^{\text {st }}$ order kinetics is widely applied in the literature to model the hydrolysis step in anaerobic digestion (BATSTONE et al., 2002). Moreover $1^{\text {st }}$ order approach is applied to model anaerobic digestion of slower degradable substrates, for which the substrate disintegration/hydrolysis is considered as a rate limiting step (Llabres-Luengo and Mata-Alvarez (1987), Hahimoto (1989), Turick et al. (1991), MataAlvarez et al. (1993), Sanchez et al. (1996), Rao and Singh (2004)).

Another group of models commonly used to describe kinetics of anaerobic digestion is based on the Monod equation (MONOD, 1950, KNIGHTES \& PETERS, 2000). A model of Monod type is a function of substrate concentration but includes the influence of the bacterial growth and decay on the digestion process. Neither degradation of complex substrates (Te Boekhorst et al., 1981; Pfeffer, 1974) nor the lag phase or inhibited digestion can be precisely described by the model (Strigul et al., 2009). To improve the accuracy of Monod model in anaerobic digestion further upgrades were introduced, considering different physical and biological effects and various inhibition terms as well 
as other physical factors (MOSER, 1958; CONTOIS, 1959; POWELL, 1967; CHEN \& HASHIMOTO, 1980; BerGter, 1983; MitSDÖRfFER, 1991). Different kinetic models of this kind are reviewed extensively by PAVLOSTATHIS \& GIRALDO-GOMEZ (1991), GARCIA-HERAS (2003) and GERBER \& SPAN (2008).

Anaerobic Digestion Model No. 1 (ADM1) is the most comprehensive model applied in the field of anaerobic digestion. The model describes disintegration, hydrolysis, acidogenesis, acetogenesis and methanogenesis steps. But even ADM1 considering 19 biochemical kinetic processes combines the basics of simple first order kinetics for hydrolysis step with Monod-type kinetics used for all intracellular biochemical reactions and the inhibition functions (BATSTONE et al., 2002).

Although a lot of research has been done on modeling of anaerobic digestion steps especially for solid waste (e.g. Chen \& Hashimoto, 1980; Kiely et al., 1997; Kalfas et al., 2006; Sosnowski et al., 2007; Boubaker \& ridha, 2008; Liu et al., 2008; Vavilin et al., 2008; Qu et al., 2009) or waste water treatment (e.g. Batstone et al., 2002; Feng et al., 2006; Tomei et al., 2008; Boubaker \& ridha, 2008), not so many results can be found on modeling of agricultural biogas production (Hill \& Barth, 1977; Simeonov et al., 1996; Angelidaki et al., 1999) and only a few consider the digestion of energy crops (Wichern et al., 2008 \& 2009; Beierlein et al., 2010). The developed models, in particular the most complex ADM1, show high complexity and include a great number of parameters, which improve the accuracy of the model on one hand, but create implementation difficulties on the other hand as in many cases all data required by such models cannot be collected. Further there is no extensive comparative study on influence of change of operating mode (batch, semi-batch, continuous model) on the kinetics of anaerobic digestion.

The aim of this study was to use a kinetic model as simple as possible to describe the substrate degradation in batch, semi-batch and continuous experiments under similar conditions. In this way the modelling approach easily applicable in biogas praxis was targeted. Further, the results presented in this paper should help to close the research gap in the field of modeling energy crops digestion under thermophilic conditions especially by creating the links between different operating modes (batch, semi-batch, continuous mode) and organic loading rates.

\section{Experimental part}

\subsection{Substrate and inoculum}


The inoculum for batch, semi-batch and continuous series was obtained from a 50 I continuously fed research fermenter charged with maize and grass silage only and operated at thermophilic conditions $\left(55^{\circ} \mathrm{C}\right)$. Guidelines for the fermentation of organic material were followed (VDI, 2004). The inoculum used in batch series was recycled and reused in semi-batch and further in continuous experiments. In this way an optimum substrate adaption was attained. The details of the inoculum preparation method were described by Golkowska and Greger (2010a).

The volatile solids (VS) content of inoculum ranged between 1.2-1.8\% of fresh mass (FM) and 54 to $59 \%$ of dry mass (DM) content, except for the batch series with maize at $5.7 \mathrm{kgVS} / \mathrm{m}^{3}$. In this test the VS of the inoculum constituted only $0.59 \%$ of FM.

The ensilaged maize of two harvests was used in the experiment ( $M Z$ I for batches and semi-batches and MZ II for continuous tests). After delivery the ensilaged maize was chopped into $5 \mathrm{~mm}$ fibers, stored frozen and defrosted at low temperatures $\left(4^{\circ} \mathrm{C}\right)$ about $24 \mathrm{~h}$ before charging of the fermenters.

The composition of maize silages was analyzed by Van Soest and Weende method. A further correction of dry matter (DM) content was done according to Weißbach and Kuhla (1995). This allowed the calculation the substrate DM increased by the amount of volatile fatty acids (VFA) lost by volatilization during DM determination. The corrected composition of both maize silage harvests is given in Tab. 1. The total degradability of maize was calculated according to formula given by VDI (2004), excluding the lignin content regarded as non-degradable. The calculated biogas yield from the silages equaled $742 I_{N} / g V S$ for MZ I and $743 I_{N} / g V S$ for MZ II.

Tab. 1 Composition of maize silages MZ I and MZ II including the corrections of VFA loss according to Weißbach and Kuhla (1995)

\begin{tabular}{|c|c|c|c|c|c|c|c|c|c|c|c|c|c|}
\hline Comp & onent & DM & VS & $\begin{array}{c}\text { Crude } \\
\text { ash }\end{array}$ & $\begin{array}{l}\text { Crude } \\
\text { protein }\end{array}$ & $\begin{array}{l}\text { Crude } \\
\text { fat }\end{array}$ & NFC & NDF & ADF & $\begin{array}{c}\text { Lignin/ } \\
\text { ADL }\end{array}$ & $\begin{array}{l}\text { Hemicel } \\
\text { lulose }\end{array}$ & $\begin{array}{l}\text { Cellu } \\
\text { lose }\end{array}$ & VFA \\
\hline Un & & $\% \mathrm{FM}$ & $\% \mathrm{FM}$ & \multicolumn{10}{|c|}{$\%$ DM } \\
\hline \multirow{2}{*}{ Maize } & MZ I & 33.9 & 32.6 & 4.1 & 6.7 & 3.2 & 43.2 & 40.1 & 26.3 & 3.5 & 13.8 & 22.8 & 2.7 \\
\hline & MZ II & 33.4 & 32.2 & 3.3 & 7.3 & 2.8 & 49.4 & 34.4 & 22.3 & 3.5 & 12.0 & 18.8 & 2.8 \\
\hline
\end{tabular}

\subsection{Set up and analytical methods}

Three types of experiments under thermophilic conditions $\left(55^{\circ} \mathrm{C}\right)$ were performed during the study: batch, semi-batch and continuous digestion of maize silage. The details concerning the applied OLRs, feeding frequency and maize harvest are presented in Tab. 
Tab. 2 Overview of the test series performed during the study

\begin{tabular}{|c|c|c|c|c|c|c|}
\hline \multirow{2}{*}{$\begin{array}{l}\text { maize } \\
\text { silage }\end{array}$} & \multirow[b]{2}{*}{ mode } & \multicolumn{4}{|c|}{ single feeding OLR $\left[\mathrm{kgVS} / \mathrm{m}^{3}\right]$} & \multirow{2}{*}{$\begin{array}{l}\text { Feeding } \\
\text { frequency }\end{array}$} \\
\hline & & 4.1 & $\begin{array}{c}5.8 \pm \\
0.1\end{array}$ & $\begin{array}{r}11.6 \\
\pm 0.2 \\
\end{array}$ & $\begin{array}{r}17.3 \\
\pm 0.3 \\
\end{array}$ & \\
\hline MZI & batch & - & $x$ & $x$ & $x$ & 1 per test \\
\hline MZI & semi-batch & - & $x$ & $x$ & $x$ & $\begin{array}{l}1 \text { per } 3 \text { days } \\
10 \text { times }\end{array}$ \\
\hline MZ II & conti & $x$ & $x$ & $x$ & - & $\begin{array}{l}1 \text { per day } \\
10 \text { times }\end{array}$ \\
\hline
\end{tabular}

Only the part of the experimental set up and analytical methods relevant for this paper is presented in this chapter. The results irrelevant for the part of the study described in this article were displayed and analyzed in separate publications (Golkowska \& Greger $2010 b, 2012 a-b)$.

\section{Batch experiments}

Batch experiments were conducted in $1 \mathrm{I}$ fermenting bottles filled with $700 \mathrm{~g}$ of inoculum each. In all batch series the reactors were opened only once at the beginning of the experiment as the substrate was introduced into reactor. For each experimental series 12 - 18 reactor bottles were prepared and run parallel under the same conditions. The higher OLR was investigated, the more reactors were run in parallel. This was essential due to a longer GP period creating the necessity of more reactor samplings. For each series a separate reactor was run with the inoculum only to qualify the background production. Depending on the investigated OLR 6-13 reactors were used for sampling purposes. At particular stages of digestion the reactors were stopped, then the digestate was homogenised by shaking and sampled for DM and VS content. Each time only one reactor was stopped for sampling purposes. Once stopped, the reactor was not used for the further study to prevent the disruption of digestion by air inflow.

The daily and total mean GP value, as well as the statistical significance of the GP (expressed in standard deviation), were calculated basing on the GP received from 2-3 biogas reactors. The digestion was regarded as completed when the GP was smaller than $5 \mathrm{ml}$ within a period of 3 days.

\section{Semi-batch and continuous experiments}

The experimental series in semi-batch and continuous mode were prepared in the similar way. Fermentation took place in $2 \mathrm{I}$ fermenting bottles filled with $700 \mathrm{~g}$ of inoculum each. In each series all reactors were charged 10 times: in semi-batch every third day while in continuous mode every day. This means that the full charging period 
in semi-batch lasted for 30 days while in continuous mode the feeding period was terminated after 10 days. During continuous digestion at OLR of $11.7 \mathrm{kgVS} / \mathrm{m}^{3}$ several signs of digestion disturbance (the olfactometric analysis of the biogas, the low GP and its final cease) caused the experiment being terminated already after the feeding 6 .

For each test series and experimental mode a set of 8 fermenter bottles was run in parallel. One reactor was used for capturing the background production. The GP from 2 reactors was measured and used to calculate the mean and total GP as well as the statistical significance of the measured values (expressed in standard deviation). The reactors were reopened for the feeding purposes. After the feeding period the substrate was left in the reactors until the GP ceased, which was assumed when the GP did not exceed the sum of $5 \mathrm{ml}$ for a 3 -day period.

For direct comparison of semi-batch and continuous mode results a daily OLR was calculated for semi-batch mode by dividing of total single OLR by the period of 3 days corresponding to the length of a feeding interval (for details s. Golkowska, 2011).

\section{Biogas volume and volatile solids}

The biogas was collected in a gas trap by displacement of saturated saline water to minimize biogas solubility in the water. Its volume was converted into standard temperature and pressure conditions $(273.15 \mathrm{~K}, 1013.25 \mathrm{hPa})$. The observed differences in the GP form different reactors of the same series did not exceed $10 \%$, which is assumed as the biological diversity typical for experiments conducted on living organisms (HELFFRICH \& OECHSNER, 2003).

Dry matter (DM) and volatile solids (VS) of substrate and inoculum were determined according to DIN EN ISO 12879 and 12880. The homogenous reactor content or substrate sample was dried $24 \mathrm{~h}$ (if necessary longer) at $105^{\circ} \mathrm{C}$ for DM analysis and carbonized $24 \mathrm{~h}$ at $550^{\circ} \mathrm{C}$ for VS determination. Each sample was analyzed twice. The reproducibility of the DM and VS results for substrates and reactor samples was not lower than 95\%.

\section{Model development}

\subsection{Volatile solids data}

In the batch tests the VS of the reactors was regularly measured during degradation. These values were used to calculate substrate degradation level. The results turned out to be inconsistent and varied considerably. For some tests e.g. $5.7 \mathrm{~kg} \mathrm{VS} / \mathrm{m}^{3}$ measured VS values were not following a decreasing trend (s. Fig 1, S_measured_VS). Similar difficulties occurred in further experiments for different substrates and temperature 
modes (Golkowska, 2011). The observed problems were connected to the specific of the material (substrate and inoculum) used in the study. In the reactors maize was floating on the inoculum surface during sampling. Furthermore, as noticed already by CHEN \& HASHIMOTO (1978), some VS volatilise during DM and VS determination, which causes additional inaccuracy in calculating the VS amount. Consequently the VS values were not exact enough to be used for further analysis.

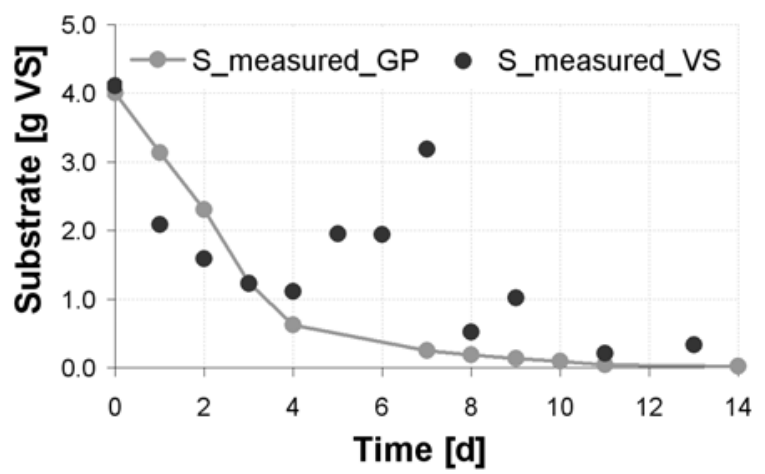

Fig 1 Two methods of calculation for substrate degradation: from measured volatile solids (VS) content or from gas production (GP) according modified Chen \& Hashimoto (1978) equation (s. Eq. 1) for $5.7 \mathrm{kgVS} / \mathrm{m}^{3}$ in batch mode

Similar problems were already reported by CHEN \& HASHIMOTO (1978), who developed an equation allowing conversion of measured methane volume into substrate degradation. The equation follows the assumption that for non-inhibitory anaerobic digestion the methane production is directly linked to substrate reduction and no other way of substrate degradation is possible.

Chen \& Hashimoto equation has been widely applied for calculation of different substrates especially if GP is the only reliable data characterising the digestion process. However the equation in the form proposed by the authors did not enclose the substrate degradation selectivity towards methane and therefore assumes the constant fraction of $\mathrm{CH}_{4}$ in biogas. While such estimation could be accepted for continuous experiments, it is definitely invalid for semi-batch and even more for batch experiments, in which the $\mathrm{CH}_{4} / \mathrm{CO}_{2}$ ratio varies seriously for at least 3 initial days of digestion. To improve the accuracy of the results the Chen $\&$ Hashimoto equation was applied in a modified form, in which not the methane but biogas data was implemented (s. Eq. 1). This approach allowed a more accurate substrate to product conversion and gave satisfactory data for modelling. An exemplary comparison of VS substrate degradation calculated from VS values and from biogas data is presented in Fig. 1. 
Where:

$$
\frac{S}{S_{0}}=\frac{B_{e n d}-B}{B_{\text {end }}}
$$

$\mathrm{S}$ - substrate concentration at time $\mathrm{t}$

$\mathrm{S}_{0}$ - initial substrate concentration (at time $\mathrm{t}_{0}$ )

$B$ - biogas produced at time $t$

$B_{\text {end }}$ - total biogas production (at time $t_{\text {end }}$ )

\subsection{Substrate degradation kinetics}

In the study the first order kinetics was applied to fit the degradation curves (s. Eq. 2). In modelling usually this kinetic approach is used to fit the hydrolysis step of anaerobic digestion or degradation of slowly biodegradable substrates, for which disintegration/hydrolysis can be considered as the rate limiting step. In the following approach no intermediate steps were considered. The curve fitting was done following the least squares method.

$$
\frac{d S}{d t}=-k S
$$

Where:

$$
\begin{aligned}
& \text { S- Substrate concentration [g VS/l] } \\
& \text { t- Time [d] } \\
& \text { k - First order kinetic constant }\left[d^{-1}\right]
\end{aligned}
$$

\section{Results}

In the initial approach measured substrate uptake data were fitted with the similar value of first order kinetic constant. However no good data fit was obtained by the model. Consequently different kinetic parameter values were adapted separately for each degradation curve.

The $1^{\text {st }}$ order curves were fitted for 3 OLRs in batch (s. Fig. 2), 3 OLRs in semi-batch and 2 OLRs in continuous mode (exemplary curves shown in Fig. 3). The complete set of kinetic parameters received for $1^{\text {st }}$ order fit for all operating modes is presented in Tab. 3 and Tab. 4. In general a good 1 st order fit was achieved for the substrate degradation independent of OLR and operating mode. 

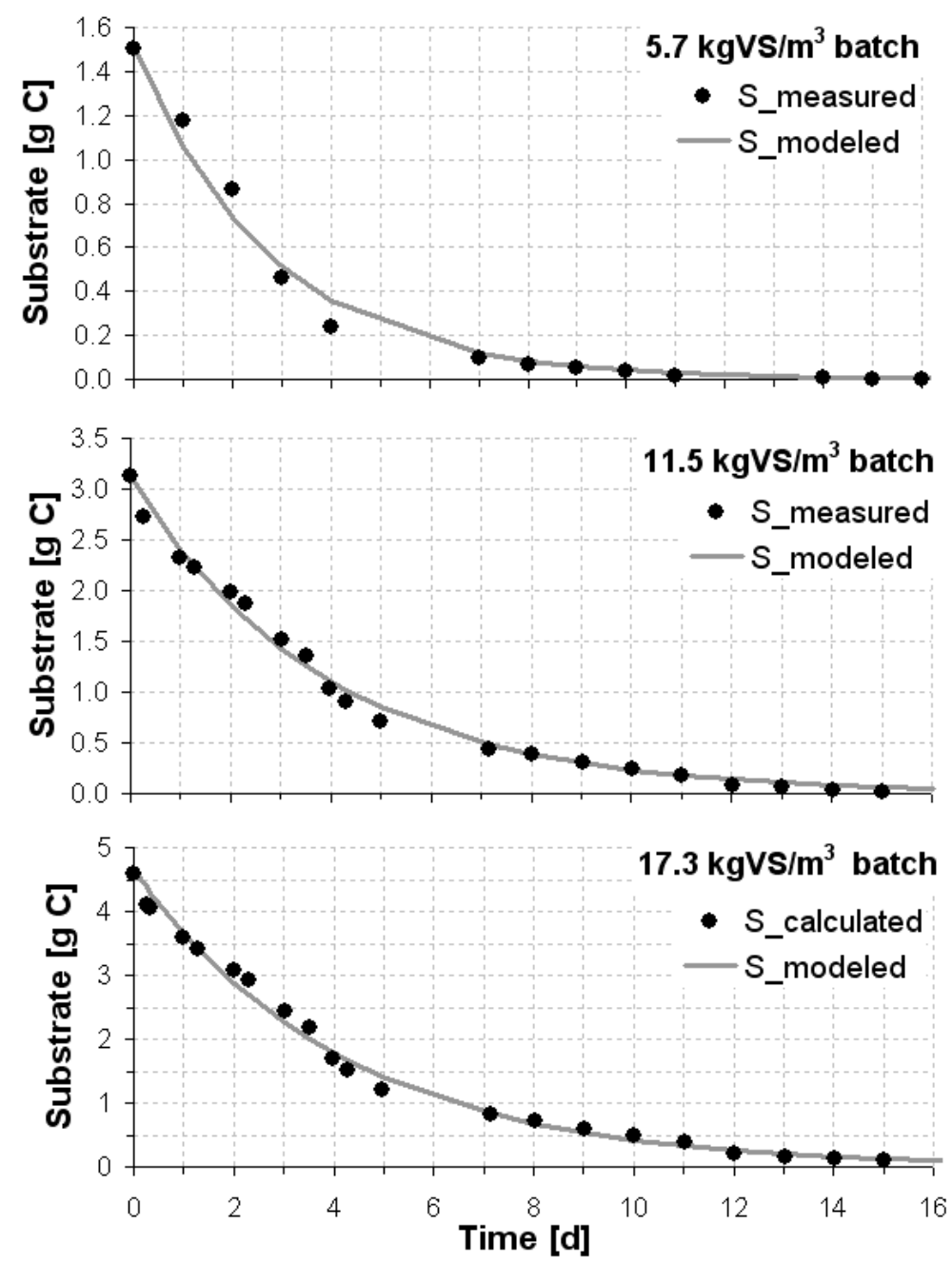

Fig. 2 Modeled and calculated substrate degradation of maize silage in batch mode for increasing organic loading rates

In batch mode, the lower the OLR was, the faster degradation rate could be observed. A stronger decrease of $1^{\text {st }}$ order constants was observed between $5.7 \mathrm{kgVS} / \mathrm{m}^{3}$ and $11.5 \mathrm{kgVS} / \mathrm{m}^{3}$ while the difference between parameter values fitted for $11.5 \mathrm{kgVS} / \mathrm{m}^{3}$ and $17.3 \mathrm{kgVS} / \mathrm{m}^{3}$ was not that explicit. For $11.5 \mathrm{kgVS} / \mathrm{m}^{3}$ in batch mode the fitted $\mathrm{k}$ value of $0.26 \mathrm{~d}^{-1}\left(\mathrm{k}_{\mathrm{b}}\right)$ was by $28 \%$ lower than for $5.7 \mathrm{kgVS} / \mathrm{m}^{3}\left(\mathrm{k}_{\mathrm{a}}\right)$. A further reduction of $\mathrm{k}$ from $11.5 \mathrm{kgVS} / \mathrm{m}^{3}$ to $17.3 \mathrm{kgVS} / \mathrm{m}^{3}$ reached only $\equiv$ of the parameter value $\mathrm{k}_{\mathrm{a}}$ (s. Tab. 3).

Tab. 3 Summary of $1^{\text {st }}$ order constants obtained for thermophilic digestion of maize silage in batch mode and their comparison 


\begin{tabular}{cccccc}
\hline series & $\begin{array}{c}\text { OLR } \\
{\left[\mathbf{k g V S} / \mathbf{m}^{3}\right]}\end{array}$ & $\begin{array}{c}\mathbf{S}_{0} \\
\text { measured } \\
\text { [g VS] }\end{array}$ & $\begin{array}{c}\mathbf{S}_{0} \\
\text { modelled } \\
\text { [g VS] }\end{array}$ & $\begin{array}{c}\mathbf{k} \\
{\left[\mathbf{d}^{-1}\right]}\end{array}$ & $\begin{array}{c}\mathbf{k}_{\mathbf{n}} / \mathbf{k}_{\mathbf{a}} \\
\mathbf{n}=\{\mathbf{a}, \mathbf{b}, \mathbf{c}\}\end{array}$ \\
\hline $\mathrm{a}$ & 5.7 & 4.00 & 4.03 & 0.36 & $100 \%$ \\
$\mathrm{~b}$ & 11.5 & 8.05 & 8.05 & 0.26 & $72 \%$ \\
$\mathrm{c}$ & 17.3 & 12.08 & 12.24 & 0.24 & $67 \%$ \\
\hline
\end{tabular}

In semi-batch and continuous experiments each feeding was modeled separately. Certain feeding periods were excluded from modeling as not sufficient number of GP data was available (s. Fig. 3 and Tab. 4).

The $k_{1}$ values of $0.21-0.23 d^{-1}$ in semi-batch mode were similar to the $k$ obtained for the highest OLR in batch, while the maximum $k$ value $\left(k_{4}=0.34 \mathrm{~d}^{-1}\right)$ fitted in semi-batch for $5.9 \mathrm{kgVS} / \mathrm{m}^{3}$ was close to the $\mathrm{k}=0.36 \mathrm{~d}^{-1}$ obtained for $5.7 \mathrm{kgVS} / \mathrm{m}^{3}$ in batch mode.

In continuous mode $\mathrm{k}_{1}$ decreased considerably with the increase of OLR. The $1^{\text {st }}$ order kinetic constants obtained for the same feeding periods were 1.5-2 times higher for 5.9 $\mathrm{kgVS} / \mathrm{m}^{3}$ in continuous mode than in semi-batch. The comparison of daily OLR showed that (i) for $4.1 \mathrm{kgVs} / \mathrm{m}^{3}$ in continuous mode and $11.7 \mathrm{kgVS} / \mathrm{m}^{3}\left(\approx\right.$ daily $\left.3.9 \mathrm{kgVS} / \mathrm{m}^{3}\right)$ in semi-batch $k_{1}-k_{10}$ values nearly doubled with the tripling of the feeding frequency, while (ii) for $5.9 \mathrm{kgVS} / \mathrm{m}^{3}$ in continuous mode and $17.6 \mathrm{kgVS} / \mathrm{m}^{3}\left(\approx\right.$ daily $\left.5.9 \mathrm{kgVS} / \mathrm{m}^{3}\right)$ in semi-batch $k_{1}$ was double as high in continuous mode but the dominance increased with every further feeding period and reached the factor of 4.5 for $k_{10}$ due to gradual $k$ drop in semi-batch. For two lower OLRs in both semi-batch and continuous mode the very final stage of accumulated substrate degradation continued at the same $k_{\text {final }}$ of $0.14-0.15 \mathrm{~d}^{-1}$. However in continuous mode $1\left(4.1 \mathrm{kgVs} / \mathrm{m}^{3}\right)$ or $4\left(5.9 \mathrm{kgVS} / \mathrm{m}^{3}\right)$ days subsequent to the feeding periods were fitted with higher $k_{\text {final }}$ of $0.31 d^{-1}$ and $0.19 d^{-1}$ respectively.

Relative stable $k$ values of $0.30-0.34 d^{-1}$ and $0.36-37 d^{-1}$ were obtained only for the lowest OLR in semi-batch and towards the end of the experiment for $5.9 \mathrm{kgVS} / \mathrm{m}^{3}$ in continuous mode respectively. These $1^{\text {st }}$ order kinetic constants were similar to the value fitted for $5.7 \mathrm{kgVS} / \mathrm{m}^{3}$ in batch mode. A stable $\mathrm{k}$ values of $0.46-0.47 \mathrm{~d}^{-1}$ might as well have been reached for $4.1 \mathrm{kgVs} / \mathrm{m}^{3}$ in continuous mode, but since they were observed only for feeding 9 and 10 it is not clear whether $\mathrm{k}$ would not have continued to decrease for the further feedings. 
For both $17.6 \mathrm{kgVS} / \mathrm{m}^{3}$ in semi-batch and $11.7 \mathrm{kgVS} / \mathrm{m}^{3}$ in continuous mode $\mathrm{k}$ values dropped nearly to 0 , however in semi-batch it occurred only toward the end of the experiment while in continuous mode already after the $4^{\text {th }}$ feeding.

In general several $k$ trends could be recognized: (i) Within every operating mode and feeding period $1^{\text {st }}$ order kinetic constants followed the decreasing trend with the increase of OLR. (ii) Within each OLR and operating mode (except for $17.6 \mathrm{kgVS} / \mathrm{m}^{3}$ in semi-batch) kinetic constants rose reaching the maximum value between feeding 2-4 and subsequent followed a decreasing trend $\left(11.7 \mathrm{kgVS} / \mathrm{m}^{3}\right.$ in semi-batch and continuous mode) or decreased to stabilize towards the end of the feeding period (5.9 $\mathrm{kgVS} / \mathrm{m}^{3}$ in semi-batch and $4.1 \mathrm{kgVS} / \mathrm{m}^{3}$ and $5.9 \mathrm{kgVS} / \mathrm{m}^{3}$ in continuous mode). (iii) For $17.6 \mathrm{kgVS} / \mathrm{m}^{3}$ in semi-batch a slow but gradual decrease of $1^{\text {st }}$ order kinetic constants was observed with every feeding. (iv) For comparable OLRs and feeding periods higher $\mathrm{k}$ values were always obtained in continuous mode.
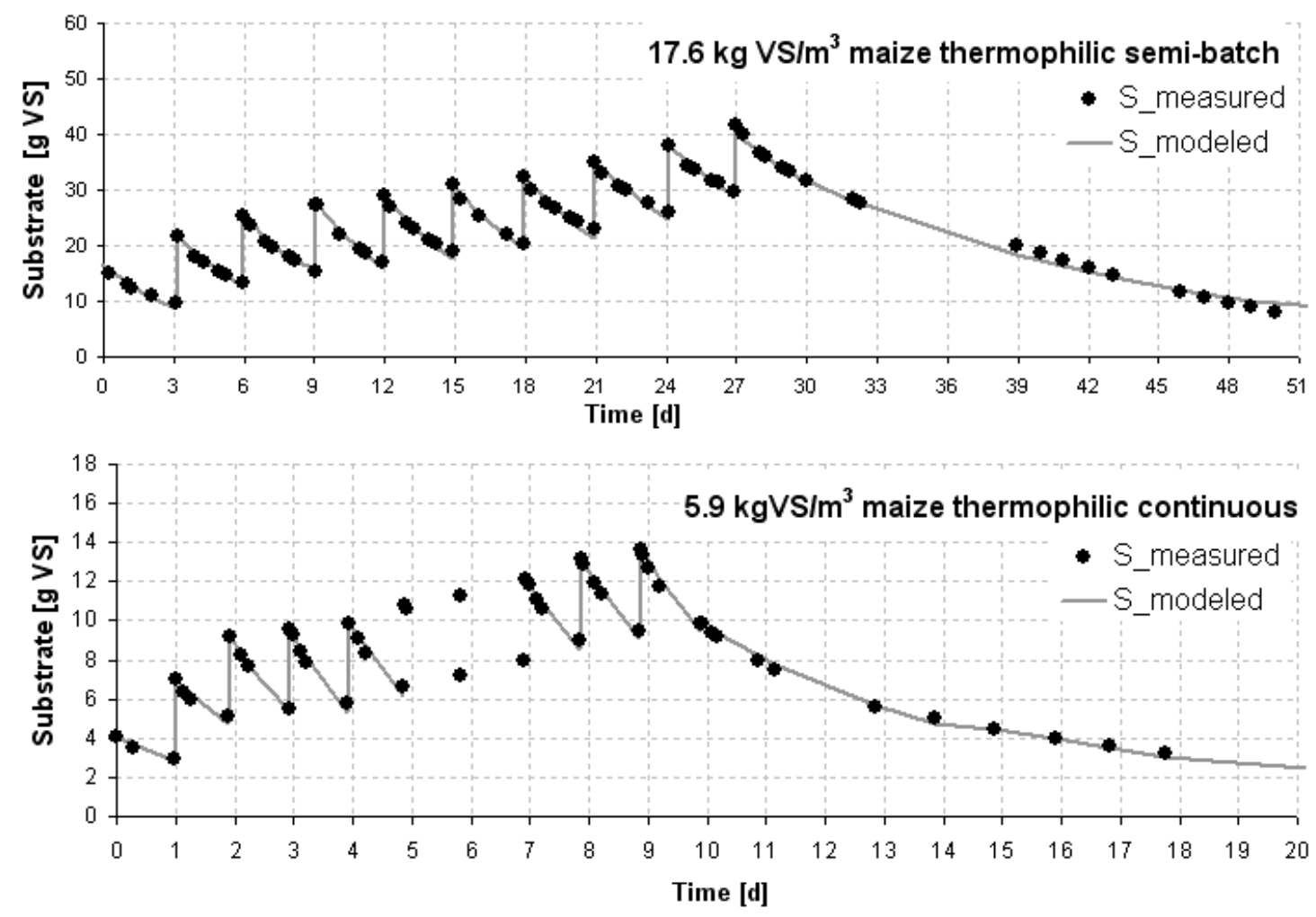

Fig. 3 Modeled and calculated 1 st order substrate degradation of maize silage for corresponding daily OLRs in semi-batch and continuous mode; the model curve in continuous mode for the post-feeding period is divided in two periods fitted with different $k$ values for days 10-14 and 14-28. 
Tab. 4 Summary of the $1^{\text {st }}$ order constants obtained in semi-batch and continuous experiments for maize silage degradation. The $\mathrm{k}_{\mathrm{final}}$ in continuous mode gives the fit for days $10-11$ and $11-21$ for $4.1 \mathrm{kgVS} / \mathrm{m}^{3}$ and for days $10-14$ and $14-28$ for $5.9 \mathrm{kgVS} / \mathrm{m}^{3}$.

\begin{tabular}{ccccccccccccc}
\hline $\begin{array}{c}\text { operating } \\
\text { mode }\end{array}$ & $\begin{array}{c}\text { OLR } \\
{\left[\mathbf{k g V S} / \mathbf{m}^{3}\right]}\end{array}$ & $\mathbf{k}_{\mathbf{1}}$ & $\mathbf{k}_{\mathbf{2}}$ & $\mathbf{k}_{\mathbf{3}}$ & $\mathbf{k}_{\mathbf{4}}$ & $\mathbf{k}_{\mathbf{5}}$ & $\mathbf{k}_{\mathbf{6}}$ & $\mathbf{k}_{\mathbf{7}}$ & $\mathbf{k}_{\mathbf{8}}$ & $\mathbf{k}_{\mathbf{9}}$ & $\mathbf{k}_{\mathbf{1 0}}$ & $\mathbf{k}_{\text {final }}$ \\
\hline \multirow{4}{*}{ semi-batch } & 5.9 & 0.23 & - & 0.33 & 0.34 & 0.31 & 0.32 & - & 0.30 & - & 0.30 & 0.14 \\
& 11.7 & 0.23 & - & 0.31 & 0.31 & 0.28 & 0.29 & - & 0.26 & - & 0.21 & 0.14 \\
& 17.6 & 0.21 & 0.19 & 0.18 & 0.19 & 0.17 & 0.16 & 0.14 & 0.11 & 0.10 & 0.08 & 0.06 \\
\hline \multirow{4}{*}{ continuous } & 4.1 & 0.64 & 0.76 & 0.81 & 0.67 & 0.69 & - & - & 0.51 & 0.47 & 0.46 & $0.31 / 0.14$ \\
& 5.9 & 0.39 & 0.43 & 0.53 & 0.60 & 0.46 & - & - & 0.37 & 0.37 & 0.36 & $0.19 / 0.15$ \\
& 11.7 & 0.30 & 0.35 & 0.20 & 0.10 & 0.03 & 0.03 & 0.01 & - & - & - & 0.002 \\
\hline
\end{tabular}

\section{Discussion}

The direct comparison of the obtained kinetic constants with the literature created certain difficulties, as in commonly applied models $1^{\text {st }}$ order equations are mainly used to define the substrate disintegration and hydrolysis. The extensive overview of first order kinetic parameters obtained for hydrolysis of carbohydrates, organic waste or energy crops is presented in Tab. 5 .

The applied maize silages contained up to $85 \%$ of carbohydrates in their structure. The literature values of disintegration/hydrolytic constants for carbohydrate containing substrates represent a very wide value range $\left(0.012-10 \mathrm{~d}^{-1}\right)$, which also covers all $\mathrm{k}$ values fitted in maize experiments $\left(0.06-0.81 d^{-1}\right)$. Good $1^{\text {st }}$ order fit for degradation of such complex substrate as maize silage and the similar value spectrum to that given in the literature for disintegration/hydrolysis suggest that for this substrate disintegration/hydrolysis step as the rate limiting factor of anaerobic digestion. This was not expected for maize silage, which had already been partially hydrolyzed in the ensiling pre-treatment. Also Llabres-Luengo and Mata-Alvarez (1987), Hahimoto (1989), Turick et al. (1991), Mata-Alvarez et al. (1993), Sanchez et al. (1996), Rao and Singh (2004) successfully used $1^{\text {st }}$ order model for kinetic study of substrate degradation (straw, municipal solid waste, woody biomass, fruit and vegetable wastes, sugar mill mud), for which the availability was considered as the digestion limiting factor. However in those research projects no pre-treated substrate was used.

Tab. $51^{\text {st }}$ order kinetic parameters for carbohydrates, organic waste or energy crops 


\begin{tabular}{lcl}
\hline \multicolumn{1}{c}{ Substrate } & $\mathbf{k} \mathbf{~ d ~}^{-1}$ ] & \multicolumn{1}{c}{ Reference } \\
\hline cellulose & 0.15 & Batstone at el., 2002 \\
food waste & 0.41 & Batstone at el., 2002 \\
solid waste & $0.11-0.17$ & Sosnowski et al., 2007 \\
carbohydrates & $0.25-10$ & Batstone at el., 2002 \\
cellulose & $0.04-0.13$ & Gujer \& Zender, 1983 \\
grass silage & 1.0 & Wichern et al., 2009 \\
cellulosic material & $0.012-0.020$ & Qu et al., 2009 \\
carbohydrates & $0.025-0.2$ & Christ et al., 2000 \\
carbohydrates & $0.5-2$ & Garcia-Heras, 2003 \\
carbohydrates & 0.35 & Kalfas et al., 2006 \\
\hline
\end{tabular}

Although useful for maize silage, $1^{\text {st }}$ order approximation is not applicable for modelling of the degradation of any substrate, e.g. cellulose fermentation could not be fitted with 1 st order curves but a very good fit succeeded with a Monod equation (s. Golkowska, $2011)$.

Due to the rapid decline of $\mathrm{k}$ values, the results of $1^{\text {st }}$ order fit confirmed without a doubt the inhibition of the digestion at $17.6 \mathrm{kgVS} / \mathrm{m}^{3}$ in semi-batch and $11.7 \mathrm{kgVS} / \mathrm{m}^{3}$ in continuous mode. For uninhibited series $\left(5.9 \mathrm{kgVS} / \mathrm{m}^{3}\right.$ and $11.7 \mathrm{kgVS} / \mathrm{m}^{3}$ in semibatch; $4.1 \mathrm{kgVS} / \mathrm{m}^{3}$ and $5.9 \mathrm{kgVS} / \mathrm{m}^{3}$ in continuous mode) each increase of OLR independent of the operating mode resulted in a decrease of the first order coefficients. This suggests that the anaerobic digestion at the lowest OLR continued always with the highest rate and for each of the operating modes tested the lowest OLR can be assumed as the most optimal to obtain the fastest conversion. It cannot be excluded that a lower not investigated OLR would give even higher digestion rates.

According to kinetic coefficients the stable digestion rate was achieved for $5.9 \mathrm{kgVS} / \mathrm{m}^{3}$ in both continuous ( $5.9 \mathrm{kgVS} / \mathrm{m}^{3}$ daily) and semi-batch mode $\left(\sim 5.9 \mathrm{kgVS} / \mathrm{m}^{3}\right.$ per 3 days $=2.0 \mathrm{kgVS} / \mathrm{m}^{3}$ daily), even though in semi-batch this state was attained already for the third feeding period $\left(\mathrm{k}_{3}\right)$ while in continuous mode only for the eighth one $\left(\mathrm{k}_{8}\right)$. A steady digestion pattern can also be presumed for $4.1 \mathrm{kgVS} / \mathrm{m}^{3}$ in continuous mode beginning with $k_{9}$ but the feeding stop after the $10^{\text {th }}$ charge did not allow the verification of this presumption. A longer experimental series would be required to confirm the findings. 
For that purpose however unlike to the applied methodology real chemostat ${ }^{1}$ conditions would be necessary.

The shorter total degradation time was fitted in batch mode by the model, the higher $\mathrm{k}$ values were obtained. In batch mode the highest $k=0.36 \mathrm{~d}^{-1}$ was achieved for the lowest OLR with total degradation time of $10 \mathrm{~d}$. For both higher OLRs a nearly similar $\mathrm{k}$ of $0.24 d^{-1}-0.26 d^{-1}$ was fitted, while the total digestion time for both series reached 13 d. Similar dependency was reported by Liebeneiner (2010), who compared reaction kinetics for batch digestion of different energy crops as a function of digestion time. In this approach the author obtained similar $\mathrm{k}$ of $0.25 \mathrm{~d}^{-1}$ for thermophilic maize silage conversion into biogas. The $\mathrm{k}$ value of $0.36 \mathrm{~d}^{-1}$ for $5.7 \mathrm{kgVS} / \mathrm{m}^{3}$ in batch mode was higher than for two other OLRs. This might have also been caused by a lower bacterial activity and gas production observed in the final stage of degradation at $5.7 \mathrm{kgVS} / \mathrm{m}^{3}$ (s. Golkowska, 2011). In consequence the model fitted only the fastest part of the digestion hence the higher $\mathrm{k}$ value was obtained.

For comparable feedings in semi-batch and continuous mode, the time available for the undisturbed digestion of each feed was with $3 \mathrm{~d}$ and $1 \mathrm{~d}$ respectively as long as the feeding intervals. It could be clearly seen that for all series (except for $17.6 \mathrm{kgVS} / \mathrm{m}^{3}$ in semi-batch and $11.7 \mathrm{kgVS} / \mathrm{m}^{3}$ in continuous mode) much higher first order constants were fitted in continuous mode than in semi-batch.

With each increase of the feeding frequency and the related reduction of retention time from semi-batch to continuous mode an increase of degradation rate was observed. According to the kinetic parameters the anaerobic biocenosis managed to degrade nearly the same substrate amount within a two times shorter period. The increase of bacterial productivity with shortening of retention time was also confirmed by the specific gas production rates measured for the same experiments, even though these values suggested the raise of the degradation rate even by a factor of three (Golkowska, 2011). Such high and fast adaption ability to the increased feeding frequency and higher daily OLRs was not reported elsewhere. The discrepancy between the modelling and specific gas production data can be seen as a consequence of the modelling curves fitting in semi-batch more data points than in continuous mode.

The $k$ final values of $0.14 d^{-1}-0.15 d^{-1}$, obtained for semi-batch and after 1-4 day delay for continuous mode, give the $1^{\text {st }}$ order kinetics coefficient of undisturbed

\footnotetext{
1 In chemostat culture each reactor loading is accompanied by removal of respective amount of digestate. This was not the case in the semi-batch and continuous series, in which only sporadic small amounts of effluent for analytical purposes were taken out of the reactor.
} 
digestion for the slowly degradable fractions of maize. Such data can be helpful to biogas plant designers for the dimensioning of a secondary digester/storage tank of a plant charged with maize silage.

\section{Conclusions}

The results of the presented modelling approach revealed that the simple $1^{\text {st }}$ order fitting can help in analyzing performance of a biogas fermenter fed with ensilaged maize even if the GP is the only available process parameter. However, the applicability of the $1^{\text {st }}$ order modeling for different energy crops cannot be assumed, since it strongly depends on the substrate composition and degradation performance.

The applicability of the $1^{\text {st }}$ order fit for modelling of anaerobic degradation of maize despite the ensiling pre-treatment shows, that primarily the disintegration/hydrolysis step determined the total degradation rate of the substrate. The analysis of first order rate coefficients revealed two inhibited OLRs $\left(17.6 \mathrm{kgVS} / \mathrm{m}^{3}\right.$ in semi-batch and 11.7 $\mathrm{kgVS} / \mathrm{m}^{3}$ in continuous mode). An extremely high adaption capability of anaerobic biocenosis to increased loading frequency was shown in semi-batch and continuous tests. The highest substrate to biogas conversion rates were measured for the lowest investigated OLRs for all operating modes, nevertheless the stabilized digestion was measured for $5.9 \mathrm{kgVS} / \mathrm{m}^{3}$ both in semi-batch and continuous mode. No further conclusion considering the digestion stability for particular OLRs or optimum OLR can be done, since too short period of digestion was investigated for such observation.

\section{References}

D. Batstone, J. Keller, I. Angelidaki, S. Kalyuzhnyi, S. Pavlostathis, A. Rozzi, W. Sanders, H. Siegrist, V. Vavilin, Anaerobic Digestion Model No 1 (ADM1), IWA Publishing 2002.

P. Llabres-Luengo, J. Mata-Alvarez, Biomass 1987, 14, 129-142.

A. G. Hashimoto, Biol. Waste. 1989, 28(4), 247-255.

C. E. Turick, M. W. Peck, D. P. Chynoweth, D. E. Jerger, E. H. White, L. Zsuffa, A. W. Kenney, Bioresource Technol. 1991, 37(2), 141-147. DOI: 10.1016/09608524(91)90202-U.

J. Mata-Alvarez, A. Mtz.-Viturtia, P. Llabres-Luengo, F. Cecchi, Biomass Bioenerg. 1993, 5(6), 481-488. DOI: 10.1016/0961-9534(93)90043-4.

E. Sanchez, R. Borja, M. Lopez, Bioresource Technol. 1996, 56 (2-3), 245-249. DOI:

10.1016/0960-8524(96)00037-5.

M. S. Rao, S. P. Singh, Bioresource Technol. 2004, 95(2), 173-185. DOI:

10.1016/j.biortech.2004.02.013. 
J. Monod, Ann. Inst. Pasteur 1950, 79(4), 390- 410.

C. Knightes, C. Peters, Biotechnol. Bioeng. 2000, 69(2), 160-170.

R. Te Boekhorst, J. Ogilvie, J. Pos, Livestock Waste: A Renewable Resource 1981, 2, $105-$ 108.

J. T. Pfeffer, Biotechnol. Bioeng. 1974, 16(6), 771-787.

N. Strigul, H. Dette, V. Melas, Envrion. Modell. Softw. 2009, 24(9), 1019-1026.

DOI: 10.1016/j.envsoft.2009.02.006

$\mathrm{H}$. Moser, The Dynamics of Bacterial Populations Maintained in the Chemostat.

Publication 614, Carnegie Institution of Washington, Washington DC, 1958.

D. Contois, J. Gen. Microbiol. 1959, 21, 40-50.

E. Powell, in Proc. of the Microbial Physiology and Continuous Culture, 3rd International Symposium, (Eds: E. Powell, C. Evans, R. Strange, D. Tempest), Salisbury 1967.

Y. Chen, A. G. Hashimoto, Biotechnol. Bioeng. 1980, 22(10), 2081-2095, DOI: $10.1002 /$ bit.260221008.

F. Bergter, Wachstum von Mikroorganismen: Experimente und Modelle, VEB Gustav Fisher Verlag, Jena 1983.

R. Mitsdörffer, Charakteristika der zweistufigen thermophilen/mesophilen

Schlammfaulung unter Berücksichtigung kinetischer Ansätze, Berichte aus Wassergüteund Abfallwirtschaft, No. 109, Technische Universität München 1991.

S. Pavlostathis, E. Giraldo-Gomez, Crit. Rev. Env. Contr. 1991, 21(5-6), 411-490.

Biomethanization of the Organic Fraction of Municipal Solid Wastes (Eds:

J. Mata-Alvarez), IWA Publishing 2003.

M. Gerber, R. Span, in International Gas Union Research Conference Paper, Paris 2008.

G. Kiely, G. Tayfur, C. Dolan, K. Tanji, Water Res. 1997, 31 (3), 534-540.

DOI: 10.1016/S0043-1354(96)00175-3.

H. Kalfas, I. V. Skiadas, H. N. Gavala, K. Stamatelatou, G. Lyberatos, Water Sci. Technol. 2006, 54(4), 149-156. DOI: 10.2166/wst.2006.536.

P. Sosnowski, A. Klepacz-Smolka, K. Kaczorek, S. Ledakowicz, Bioresource Technol. 2008, 99(13), 5731-5737. DOI: 10.1016/j.biortech.2007.10.019.

F. Boubaker, B. C. Ridha, Bioresource Technol. 2008, 99(14), 6565-6577.

DOI: $10.1016 / \mathrm{j}$.biortech.2007.11.035.

C. Liu, X. Yuan, G. Zeng, W. Li, J. Li, Bioresource Technol. 2008, 99(4), 882-888.

DOI: $10.1016 /$ j.biortech.2007.01.013.

V. A. Vavilin, B. Fernandez, J. Palasti, X. Flotats, Waste Manage. 2008, 28(6), 939-951. DOI: $10.1016 /$ j.wasman.2007.03.028.

X. Qu, V. A. Vavilin, L. Mazéas, M. Lemunier, C. Duquennoi, P.-J. He, T. Bouchez, Waste Manage. 2009, 29 (6), 1823-1837. DOI: 10.1016/j.wasman.2008.12.008.

Y. Feng, J. Behrendt, C. Wendland, R. Otterpohl, Water Sci. Technol. 2006, 54(4), 139 147. DOI: $10.2166 /$ wst.2006.535. 
M. Tomei, C. Braguglia, G. Mininni, Bioresource Technol. 2008, 99(14), 6119-6126.

DOI: 10.1016/j.biortech.2007.12.035.

D. T. Hill, C. L. Barth, JWPCF 1977, 49(10), 2129-2143.

I. Simeonov, V. Momchev, D. Grancharov, Water Res. 1996, 30(5), 1087-1094.

I. Angelidaki, L. Ellegaard, B. K. Ahring, Biotechnol. Bioeng. 1999, 63(3), 363-372.

M. Wichern, M. Lübken, M. Schlattmann, A. Gronauer, H. Horn, Water Sci. Technol. 2008, 58(1), 67-72. DOI: 10.2166/wst.2008.332.

M. Wichern, T. Gehring, K. Fischer, D. Andrare, M. Lübken, K. Koch, A. Gronauer, H. Horn, Bioresource Technol. 2009, 100(4), 1675-1681.

DOI: $10.1016 /$ j.biortech.2008.09.030.

N. Beierlein, K. Golkowska, M. Greger, in Proc. of the 3rd International Symposium on Energy from Biomass and Waste, Venice 2010.

VDI 4630, Fermentation of organic materials, (draft version, 08/2004), VDI-Gesellschaft Energietechnik, Fachausschuss regenerative Energien, Beuth, Berlin 2004.

K. Golkowska, M. Greger, Eng. Life. Sci. 2010, 10(6), 600-606.

DOI: 10.1002 /elsc.201000105

F. Weißbach, S. Kuhla, Übersichten zur Tierernährung, 1995, 23, 189-214.

K. G. Golkowska, M. G. Greger, Chem. Ing. Tech. 2010, 82(9), 1514.

DOI: $10.1002 /$ cite.201050046.

K. Golkowska, M. Greger, 2012, to be published.

K. Golkowska, M. Greger, 2012, to be published.

K. Golkowska, PhD. Thesis, University of Luxemburg. Luxemburg 2011.

D. Hellfrich, H. Oechsner, Agrartechnische Forschung 2003, 3, 27-30.

Characterization of sludges - Determination of the loss on ignition of dry mass, DIN EN ISO 12879, February 2001.

Characterization of sludges - Determination of dry residue and water content, DIN EN ISO 12880, February 2001.

Y. Chen, A. G. Hashimoto, in Proc. of Biotechnology and Bioengineering Symposium No. 8, 1978.

R. Liebeneiner, PhD. Thesis, Technische Universität Carolo-Wilhelmina zu Braunschweig 2010.

W. Gujer, A. J. B. Zehnder, Water Sci. Technol. 1983, 15(8-9), 127-167.

O. Christ, P. A. Wilderer, R. Angerhöfer, M. Faulstich, Water Sci. Technol. 2000, 41 (3), 61-65. 